\title{
Tailings Pond Life Cycle Safety Management System
}

\author{
Quanming $\mathrm{Li}^{1 *}$, Hong Zhang ${ }^{2}$ and Gang $\mathrm{Li}^{3}$ \\ ${ }^{1}$ China Academy of Safety and Science \& Technology, Beijing, China \\ ${ }^{2}$ Faculty of Safety Engineering, North China Institute of Science \& Technology, Langfang, China \\ ${ }^{3}$ China Academy of Safety and Science \& Technology, Beijing, China
}

\begin{abstract}
China, a globally recognized major mining country, holds one of the largest quantities of tailings pond country in the world. The total number of mines in China has been ranked first in the world. It is a major concern for Chinese safety management to give great importance for tailings pond safety, stability and sustainable development. For the past few years, China has increased efforts to investigate and govern discrete issues of tailings and to carry out a series of special renovation and comprehensive treatment actions to improve safety management levels and to decrease the likelihood of tailings pond accidents. In the end of 2015, China successfully eliminated hazardous tailings ponds and dangerous tailings ponds. Moreover, the total number of tailings decreased from 12,273 to 8,869. However, there are still 1,425 "head-top" tailings that threaten the lower masses' safety. This greatly signifies the Chinese tailings pond safety, stability as well as sustainable development. In turn, this may improve the Chinese tailings life cycle safety management system and help reach the goal of attaining closed-loop management in the tailings pond life cycle. Based on the summary of the tailings pond accidents in both China and other countries from 1961 to 2015, and by analyzing the types and causes of accident, this paper investigated the successful experiences and effective measurements of British Columbia (Canada) and Australia in the tailings pond life cycle safety management. This paper summed up each country's tailings life cycle safety management requirements and analysed the characteristics and differences of tailings safety management by comparing 5 aspects: tailings life cycle safety management process, main design parameter, construction requirements, monitoring, and the tailings pond closing management. Based on these observations, this paper suggests some measurements to improve the tailings pond life cycle safety management in China, such as strengthening tailings pond safety management, improving tailings classification, increasing design parameter values, establishing mine reclamation fund, and so on.
\end{abstract}

Keywords: tailings pond, sustainable development, life cycle, safety management, China, Australia, Canada

\section{Introduction}

China holds one of the largest quantities of tailings pond country in the world. According to the State Administration of Work Safety (2013), there were 12,273 tailings at the end of 2012, including fifth grade tailings, which had a capacity of less than 1 million cubic meters of which 9,125 accounted for $74 \%$ of the total tailings. The key elements of Chinese mine safety management are tailings pond safety, stability and sustainable development. In 2013, China carried out a comprehensive governance study based on the accumulated tailings in special renovation work. Accordingly, at the end of 2015, China effectively eradicated hazardous tailings ponds and dangerous tailings ponds, and the total number of tailings decreased to 8,869 , although 1,425 "head-top" tailings still exist. Tailings pond is a major type of hazardous installation due to its high potential energy. Following a tailing accident, there will be a series of serious effects within the society and environment. By combining the contents of tailings life cycle in each stage and analyzing the tailings accidents that have occurred in recent years, it is well known that tailings accidents not only happened during monitoring, but also happened in other stages, such as construction and closure. For instance, a waste dam failure accident that occurred in Brazil in 2001 led to the death of two people and left three workers missing. At least 113 people died in the waste heap failure accident in Myanmar in 2015. These events hold great significance for sustainable Chinese tailings development in order to enhance tailings, create special safety facilities, establish life cycle safety management and attain the goal of having tailings pond life cycle closed-loop management. Presently, China has done little research in this area. Therefore, this study may provide invaluable assistance to China so as to improve the level of tailings safety management by studying the experiences of tailings life cycle safety management in Australia (Mchaina 2001, Zobaidul Kabir et al 2015, Gyozo Jordan 2008) and Canada (Easter brook 1992, Udd and Bétournay 1997, Paul Campbell 2010).

This paper summarizes the major tailings pond accidents (Wu and Mei 2014) in both China and other countries from 1961 to 2015. The amounts pertaining to accidents and deaths are shown in Figure 1.

* Corresponding Author: Q.M. Li, liqm@ casst-tec, phone: +86 15010252576

Copyright @ 2017 Canamaple Academia Services, http://press.camdemia.ca

DOI: 10.15273 /gree.2017.02.018 


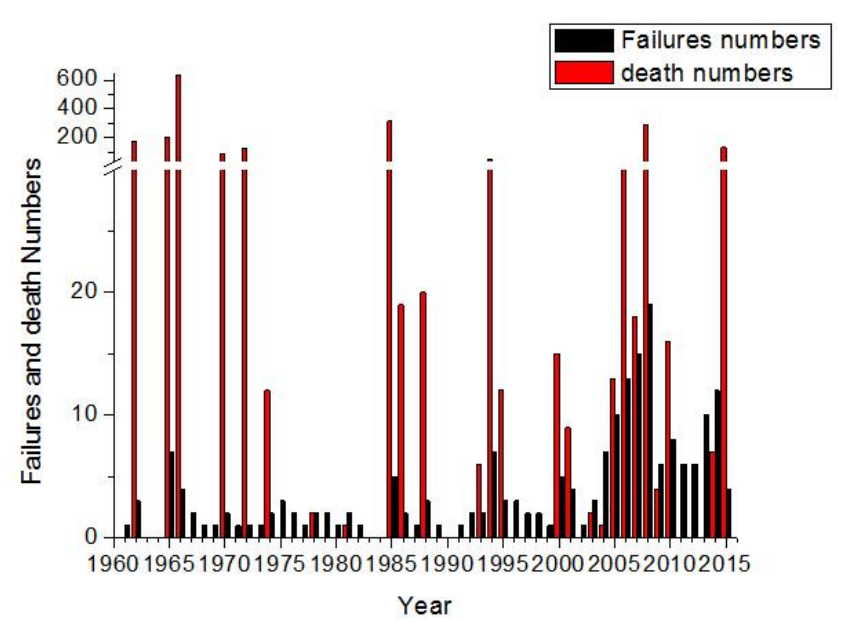

Figure 1. Accidents and deaths for global tailings pond distribution.

As shown above, a majority of the tailings accidents around the world has not reduced. Though the total number of tailings accidents is less than other mining accidents every year, the injuries and deaths, property loss and pollution caused by accidents are detrimental. Particularly, in recent years, tailings pond accidents have not been fully controlled and still occur frequently.

According to an analysis of the causes relating to the disaster factors of tailings accidents (Figure 2), the main factors are dam failure and overtopping, accounting for $41.96 \%$ and $24.11 \%$, respectively, followed by earthquake and pipes damage. Therefore, the key to prevent accidents is by reducing dam failure and overtopping disasters.

During the tailings life cycle, site selection and general design are the key determinants in tailings safety. Based on proper design, the quality of construction determines whether the design standard reaches the goal. At the same time, it also determines the tailings' dam service life. Closure design is an important node contributing to tailings' sustainable development, which determines whether tailings may be reused or not after closure.

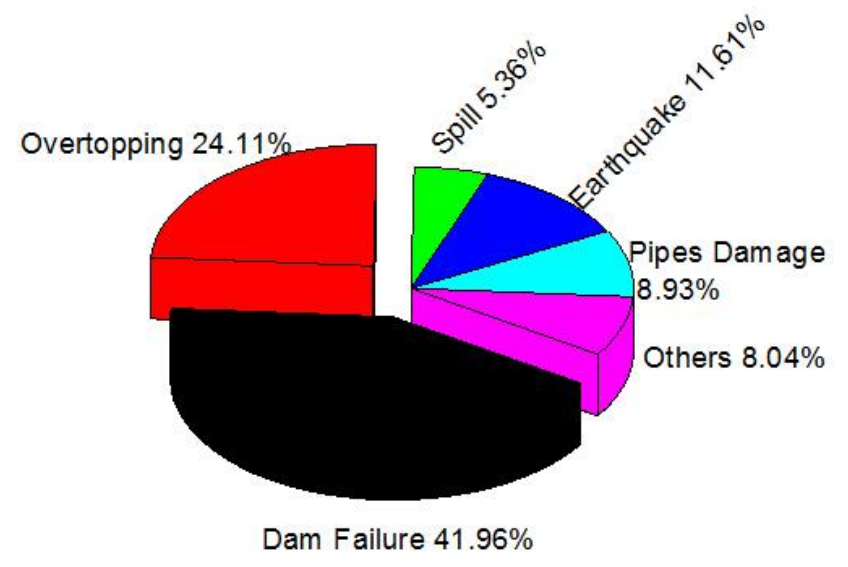

Figure 2. Analysis chart depicting reasons for tailings accidents.

\section{The Tailings Pond Life Cycle Process}

Australia has a set of detailed tailings life cycle management processes. It can be divided into three parts: (1) inputting mining information, which is the quantity of mineral deposits, surrounding geological environments and water resources information for identifying mining reserves and geographical positions; (2) mining and tailings pond management, which includes four stages - the feasible study, implementation plan, mining design and operation thus giving a clear exposition about the process and responsibilities associated with the mining development stages, from planning to closure; (3) closure and reclamation, which pertains to tailings' recycling.

The safety management process in British Columbia, Canada is also divided into three parts: (1) site selection and design, which includes the permit application, submission of mine reclamation fund, classification of dam, dam break impact analysis and so on; (2) construction and operation stage, where annual pit slope inspections should be provided annually to the office of the chief inspector, and the mining and closing procedure as well as the dam assessment revisions should be updated every five years; (3) closure, which holds that, in addition to continuing to provide the relevant annual reports of the second stage, the closure stage must also update the tailings dam management manual every five years, starting from the fifth year after closure. The process of the tailings life cycle is shown in Figure 3.

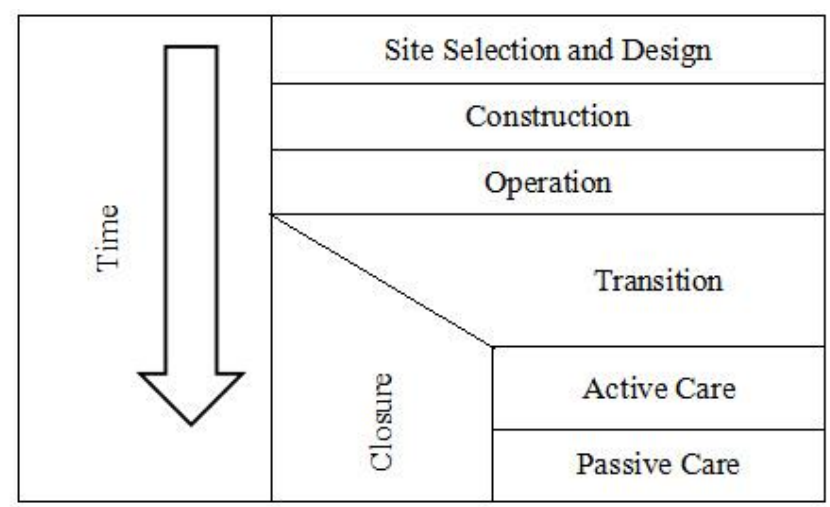

Figure 3. Tailings life cycle process of Canada.

The tailings life cycle safety management of China (Figure 4) can be divided into three stages according to the time. These stages are: (1) the mining development stage, which further consists of four stages - the decision-making stage prior to development, design stage, construction stage and project operation; (2) the tailings safety management stage, which includes four additional stages - pro-phase design preparation, tailings pond design, construction, operation and closure; (3) the tailings data archiving and reuse stage, which entails that after the tailings are closed, all archives involved in the tailings safety management in the construction, production and operation, closure and tailings reuse should be filed. The reuse of the tailings pond principally includes afforestation and reclamation. 
MINE DEVELOPMENT

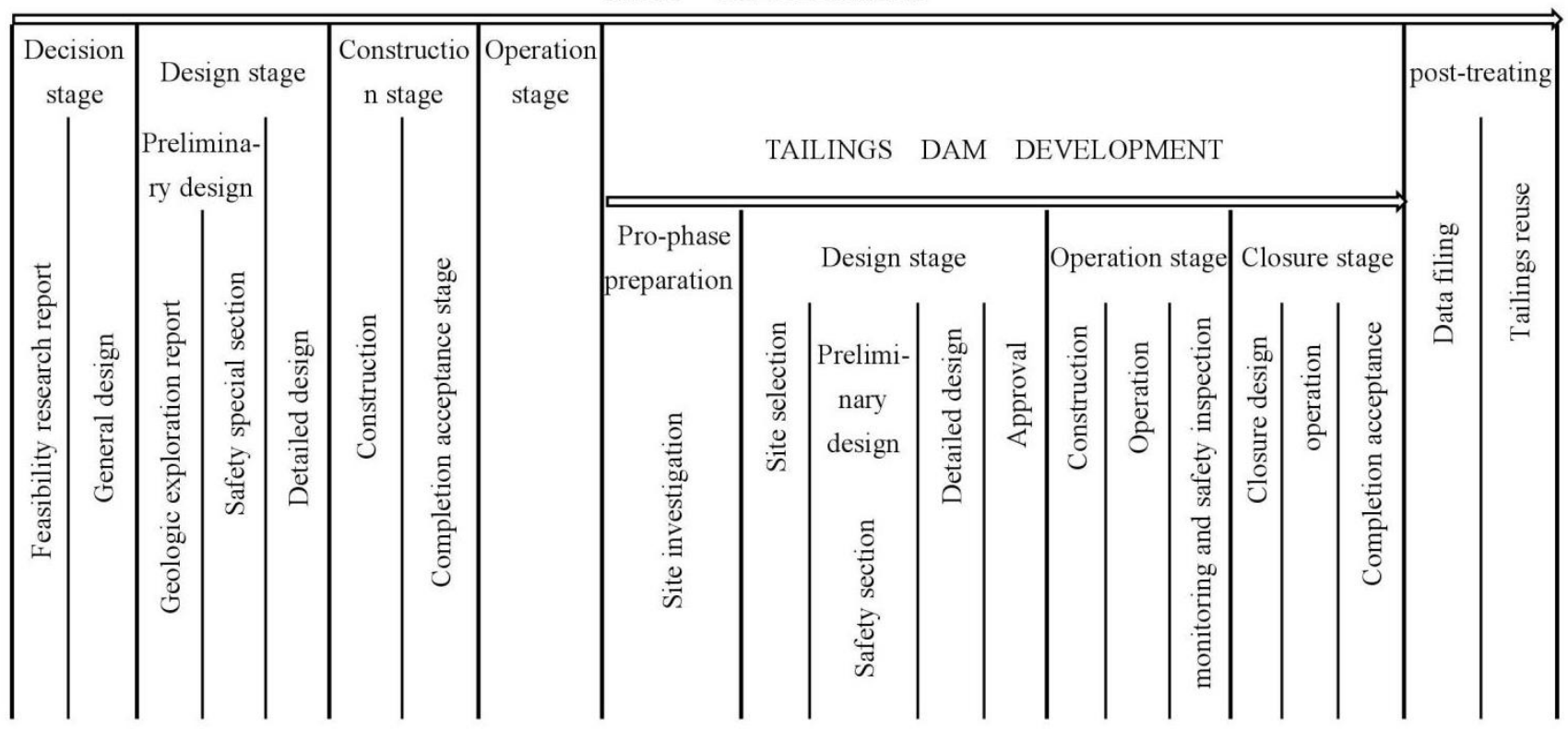

Figure 4. Tailings life cycle process of China.

\section{Main Design Parameters of the Tailings Pond}

In Australia, according to the severity of the impact to the population and in regard to the environment and economy following a dam break simulation, the tailings pond is divided into four grades: Low, Significant, High, and Extreme. During the design process, design parameters are selected per the grade of the tailings pond. The main contents of the tailings pond design include: (1) the design concept and design parameters, like the design of the spillway, drainage, seismic, flood control standard, etc.; (2) the emergency plan. The Australian standard for design flood and recommended minimums for tailings dams are shown Table 1 and Table 2.

Table 1. Design flood in Australia.

\begin{tabular}{c|cc}
\hline \multicolumn{2}{c}{ Consequence Category } & Design Flood AEP \\
\hline \multicolumn{2}{c}{ Low } & $1: 100$ \\
\hline \multicolumn{2}{c}{ Significant } & $1: 1000$ \\
\hline \multirow{2}{*}{ High } & \multirow{2}{*}{ Or } & $1: 100,000$ \\
\cline { 3 - 3 } & & PMF \\
\hline \multicolumn{2}{c}{ Extreme } & PMF \\
\hline
\end{tabular}

Table 2. Recommended minimums for tailings in Australia.

\begin{tabular}{ccc}
\hline Loading Condition & $\begin{array}{c}\text { Recommended } \\
\text { Minimum }\end{array}$ \\
\hline \multicolumn{2}{c}{ Long-term drained } & 1.5 \\
\hline \multirow{2}{*}{$\begin{array}{c}\text { Short-term } \\
\text { undrained }\end{array}$} & $\begin{array}{c}\text { potential loss of } \\
\text { containment }\end{array}$ & 1.5 \\
\cline { 2 - 3 } & no potential loss & 1.3 \\
\hline
\end{tabular}

The tailings grade and classification standards in the province of British Columbia, Canada is similar to Australia; it also divided by analyzing the severity of dam failure based on the population, environment, basic facilities and effects on the economy. Unlike Australia, tailings in British Columbia is divided into five grades: Low, Significant, High, Very High, and Extreme. The tailings design standards for British Columbia are shown in Table 3.

Table 3. Tailings design standards for British Columbia.

\begin{tabular}{|c|c|c|c|c|}
\hline \multirow[b]{2}{*}{$\begin{array}{l}\text { Dam } \\
\text { Class }\end{array}$} & \multirow{2}{*}{$\begin{array}{c}\text { Annual } \\
\text { Exceedance } \\
\text { Probability- } \\
\text { Floods }\end{array}$} & \multicolumn{3}{|c|}{$\begin{array}{c}\text { Minimum Static Factor of } \\
\text { Safety }\end{array}$} \\
\hline & & $\begin{array}{l}\text { End of } \\
\text { Constr- } \\
\text { uction }\end{array}$ & $\begin{array}{l}\text { Long } \\
\text { term }\end{array}$ & $\begin{array}{c}\text { Full or } \\
\text { Partial } \\
\text { Drawd- } \\
\text { own } \\
\end{array}$ \\
\hline Low & $\begin{array}{c}\text { 1/3 between } \\
1 / 975 \text { and } \\
\text { PMF }\end{array}$ & 1.5 & 1.5 & 1.5 \\
\hline $\begin{array}{l}\text { Signifi- } \\
\text { cant }\end{array}$ & $\begin{array}{c}\text { 1/3 between } \\
1 / 975 \text { and } \\
\text { PMF }\end{array}$ & 1.5 & 1.5 & 1.5 \\
\hline High & $\begin{array}{c}\text { 1/3 between } \\
1 / 1000 \text { and } \\
\text { PMF }\end{array}$ & 1.5 & 1.5 & 1.5 \\
\hline $\begin{array}{l}\text { Very } \\
\text { High }\end{array}$ & $\begin{array}{c}2 / 3 \text { between } \\
1 / 1000 \text { and } \\
\text { PMF }\end{array}$ & 1.5 & 1.5 & 1.5 \\
\hline Extreme & PMF & 1.5 & 1.5 & 1.5 \\
\hline
\end{tabular}

The tailings grade in China is classified according to two methods: the design grade and safety degree. The 
design grade, which is based on the capacity and the height of the tailings dam, is divided into five grades: the first, the second, the third, the fourth, and the fifth. The first is the highest grade and the fifth is the lowest. As per the flood control capacity and the stability of the dam, the tailings safety grade is divided into four grades: the dangerous pond, the risk pond, the disease pond and the normal pond. Tailings design content in China contains: (1) the safe operation control parameters, such as final dam height, the total capacity of the tailings, the normal water level of flood control, and the height of flood control; (2) safety special facilities design, which contains hidden dangers and countermeasures of the tailings, the stability analysis of the initial dam and the fill dam, the requirements of safety management, etc. Chinese design parameters were chosen according to the tailings design grade shown in Table 4.

Table 4. Design criteria of tailings pond in China.

\begin{tabular}{|c|c|c|c|c|c|c|}
\hline \multicolumn{2}{|c|}{ Dam Class } & First & Second & Third & Fourth & Fifth \\
\hline \multirow{3}{*}{ Safety factors } & normal & 1.30 & 1.25 & 1.20 & 1.15 & 1.15 \\
\hline & floods & 1.20 & 1.15 & 1.10 & 1.05 & 1.05 \\
\hline & special & 1.10 & 1.05 & 1.05 & 1.00 & 1.00 \\
\hline \multirow{2}{*}{$\begin{array}{l}\text { Flood recurrence } \\
\text { interval (a) }\end{array}$} & initial & 1 & $100 \sim 200$ & $50 \sim 100$ & $30 \sim 50$ & $20 \sim 30$ \\
\hline & Medium-late & $1000 \sim 2000$ & $500 \sim 1000$ & $200 \sim 500$ & $100 \sim 200$ & $50 \sim 100$ \\
\hline
\end{tabular}

\section{Construction Management Requirements}

During the tailings pond construction in Australia, a Responsible Engineer, who is responsible for supervision and certification during construction, needs to be chosen. In principle, the Design Engineer should be the Responsible Engineer to ensure that the design intent is achieved. However, if the conditions are not met, the Responsible Engineer and the Design Engineer should have a defined relationship to ensure attaining the design goal. All design changes during construction shall be approved by a Design Engineer so as to achieve the goal through documents or notes and revision of construction drawings. Quality Assurance and Quality Control during construction should be established. Quality Control shall be carried out by the Responsible Engineer or an independent testing company who reports to the Responsible Engineer. Quality Assurance should be followed up in time, adjusted in accordance with the actual conditions, when necessary.

In British Columbia, the Mine Manager, who is appointed by the owner, is responsible for safety management from the tailings' pre-development to postclosure. Prior to conducting any work on a mine site, the Mine Manager needs to appoint a TSF Qualified Person (Tailings Storage Facility Qualified Person) and EoR (Engineer of Record) as stipulated in the Mines Act, and submit the construction drawings, specifications, Quality Assurance, Quality Control and the information of the EoR to the Chief Inspector. The EoR is responsible for the facility design, evaluating the adequacy of the as-built facility relative to the design as well as its applicable standards, criteria and guidelines. Meanwhile, the EoR should participate in dam safety reviews, risk assessments and provide quantitative performance objectives, monitoring, and so on. The TSF Qualified Person is mainly responsible for coordinating site work alongside the EoR and recording all of the data involved in the construction. After the completion of the project, the Mine Manager shall, in accordance with the relevant provisions, submit the as-built report signed and sealed by the EoR along with the Quality Assurance and Quality Control edited by a professional engineer as well as submit other reports involved in the construction to the Chief Inspector. The tailings pond cannot operate until the license has been received. The EoR shall review the Operations, Maintenance and Surveillance (OMS) Manual, which will be implemented after the approval of the Mine Manager prior to the operation.

In China, the construction of tailings ponds mainly adopts the bidding method in order to select qualified contractors to carry out the construction. The owner entrusts a qualified supervision company with site monitoring and authentication and assigns someone to supervise. All changes shall be approved by the Design Engineer and should be informed by the supervision company by the owner submitting variation orders or notes and revised drawings. Then, the supervision company takes responsibility monitoring the contractor for construction. Major design changes require the review of a tailings original examination unit. The Quality Assurance plan shall be compiled at the construction side, and it shall be tracked and checked in time and adjusted according to the actual situation. The sample, involved in Quality Control, should be detected by qualified detection units. The detection units also need to establish test reports and submit them to the supervision engineer.

\section{Operation Monitoring Requirements}

In Australia, the company begins daily examination and maintenance after the construction of tailings is completed. The government and consulting firms carry out routine inspections and special inspections according to the consequence category. Dam safety inspection levels and the frequency of inspection are shown in Table 5. 
Table 5. Frequency of inspection and inspection levels in Australia.

\begin{tabular}{ccccc}
\hline Type of Inspection & Personnel & Extreme or High & Significant & Low \\
\cline { 2 - 5 } Comprehensive & $\begin{array}{c}\text { Dams Engineer and } \\
\text { Specialist (where } \\
\text { relevant) }\end{array}$ & $\begin{array}{c}\text { On first filling, then 5 } \\
\text { yearly }\end{array}$ & $\begin{array}{c}\text { On first filling, then 5 } \\
\text { yearly }\end{array}$ & - \\
\hline Intermediate & Dams Engineer & Annual & Annual & $\begin{array}{c}\text { On first filling, then } \\
5 \text { yearly }\end{array}$ \\
\hline Routine & $\begin{array}{c}\text { Operations } \\
\text { personnel/inspector }\end{array}$ & Daily to tri Weekly & $\begin{array}{c}\text { Twice Weekly to } \\
\text { Weekly }\end{array}$ & Monthly \\
\hline Special & $\begin{array}{c}\text { Dams Engineer and } \\
\text { Specialist }\end{array}$ & As required & As required & As required \\
\hline Emergency & Dams Engineers & - & - & - \\
\hline
\end{tabular}

PIMR (Planning, Implementation, Monitoring, Surveillance, Review and Improvement) is the core of the safety management of tailings ponds in British Columbia. Canada uses methods combined with routine inspections and periodic inspections to monitor tailings dam safety. Besides checking the safety of the tailings dam facilities, the stability of the dam slope, and the warning value, Canada also needs a professional engineer to inspect the tailings pond design, operation and performance of the structure in detail every five years. The core procedure of safety management in our country, China, is the PDCA (Plan, Do, Check, Action). The operation plan and detailed operation chart, emergency rescue plan, site practice and control, and document record are key elements in the PDCA. The safety monitoring of tailings ponds is enforced in China according to the Technical Regulations for the Tailings Pond Safety Monitoring. The design and construction of safety monitoring shall be carried out by the units with corresponding professional technology. In China, the safety inspection of tailings ponds is carried out by the combination of manual inspection and online monitoring. According to the requirements of the Technical Regulations for the Tailings Pond Safety Monitoring, the third tailings pond and above should install an online monitoring system, and the forth tailings pond is suitable for online monitoring systems.

\section{Tailings Pond Closure}

Problems related to tailings pond closure is profound in Australia. The closure program runs through the various stages of the life cycle of the Australian tailings pond in order to make closed tailings ponds deal with various risks and operate longer and steadily (1000 years or more. Firstly, as a part of the project development, the closure design and its costs should be included in the economic, social and environmental analysis of the project feasibility study. Secondly, the closure plan should be updated timely and periodically reviewed when changes in the design are made and during construction, operation and scale or direction. Thirdly, the closure plan should satisfy the longterm stability in physical, chemical, ecological and social conditions to ensure the safety of life and property and avoid unacceptable environmental risks. Closure work in Canada is also done through all stages of the tailings dam, and the closure plan must be updated every five years since the opening of the tailings pond project. The closure application and detailed plan should be submitted seven days in advance. It includes reclamation objectives, tailings disposal, protection of water resources, cost estimation and monitoring, and so on. Within 90 days after the closing of the pond, the Mine Manager should submit the drawings and other documents involved in the project to the Chief Inspector and archiving. After closing the pond, the owner, agent or Mine Manager needs to implement the relevant licensing regulations. At the same time, they should carry out on-site monitoring and maintenance plans based on closure in the OMS Manual and provide an annual report every year, including the completion of reclamation and environmental monitoring progress. To ensure the implementation of the reclamation plan, the Mines Act requires that the owner submit a mine reclamation fund to pay for the cost of the recovery of water resources or natural resources after closure.

The tailings pond closure plans in China are performed in the latter period of operation. The owners commission a qualified firm one year in advance to conduct safety evaluation of the tailings pond when the tailings pond needs to be closed. When the tailings pond has satisfied the conditions of closure, the owner can entrust a unit to design the closed tailings pond. The design of the closed tailings is mainly focused on mitigating the problems from the tailings dam remediation content and drainage system to ensure the stability of the tailings pond as well as to meet the requirements of the relevant provisions, maintain long-term safety and achieve stability of the tailings reservoir after closure.

\section{Conclusions}

By comparing the safety management of each life cycle of the tailings ponds in Australia and Canada, it is suggested that our country, China, may benefit from the following suggestions: 
(1) It is recommended to further strengthen the supervision of the whole life cycle of the tailings. The closure and the pin pond should be included in the life cycle of the tailings pond and should improve the standards of closure and reclamation in order to achieve closed-loop management of the tailings life cycle.

(2) It is suggested that the safety, economy, societal and environmental risks should be considered in the tailings pond to further improve the classification method of tailings ponds.

(3) Based on the investigation of the United States, Australia, Canada and other countries, the safety factor of the slope stability of the tailings dam is generally higher than the value of 1.5 of China. It is recommended to consider the Probable Maximum Flood (PMF) and safety factor 1.5 to improve fortification standards in flood control and dam stability factors.

(4) It is suggested that the reclamation and environmental protection fund of tailings should be paid by the mine enterprise in the tailings pond planning and design stage to guarantee that the tailings' reservoir reclamation and the environmental protection would work for a longer period in the life cycle of tailings ponds.

\section{Acknowledgement}

This research project was made possible through the financial support from the project NO. 71373245 by the National Natural Science Foundation of China.

\section{References}

Campbell, P., M. Dolbec, G. Ford, G.I. Haack, N. Heisler, W. Jolley, R. Kamel, S. Kaczmarek, L. Marcoux, C. McLean, T. Moulding, M. Passey, A. Roy, X.Q. Su, J. Theakston and K.M. Wog, 2010. Regulation of dams and tailings dams in Canada. CDA 2010 annual conference.

Easterbrook, J., 1992. MIACC (major industrial accidents council of Canada): A Canadian consensus group of stakeholders working on safety issues prior to legislation. Plant/Operations Progress, 1992, 11(3): 129 $-133$.

Udd, J.E. and M.C. Bétournay, 1997. Health, safety, and mine environments research in the mining laboratories of CANMET. Natural Resources Canada. CIM Bulletin, 90(1010): 45 - 51.

Jordan, G., 2008. Sustainable mineral resources management: From regional mineral resources exploration to spatial contamination risk assessment of mining. Environmental Geology, 58(1): 153 - 169.

Kabir, S.Z, F. Rabbi, M.B. Chowdhury and D. Akbar, 2015. A review of mine closure planning and practice in Canada and Australia. World Review of Business Research, 5(3): 140 - 159.

McHaina, D.M., 2001. Environmental planning considerations for the decommissioning, closure and reclamation of a mine site. International Journal of Surface Mining Reclamation \& Environment, 15(3): 163 - 176. DOI: 10.1076/ijsm.15.3.163.3412.

State Administration of Work Safety, 2013. No. 99. State Administration of Work Safety, Seven departments on the issuance of the summary of tailings pond special renovation work and carry out the comprehensive management of tailings action programs next. http://www.chinasafety.gov.cn/newpage/Contents/Cha nnel_5330/2013/0917/219894/content_219894.htm.

Wu, Z.Z. and G.D. Mei, 2014. Statistical analysis of tailings pond accidents and cause analysis of dam failure. China Safety Science Journal, 24(9): 70 - 76. 